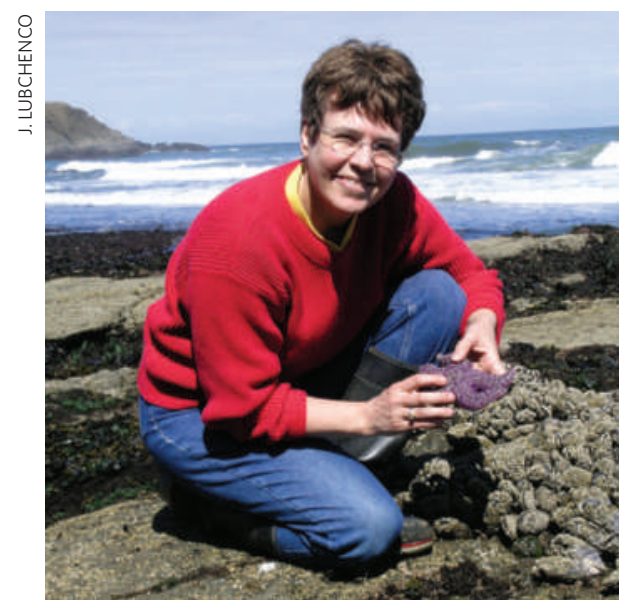

Marine star: Jane Lubchenco will run the National Oceanographic and Atmospheric Administration.

administration might work together. Nobelprizewinning physicist Steven Chu will head the Department of Energy; former Environmental Protection Agency chief Carol Browner is in a new White House position overseeing climate and energy policy. "It'll all have to be coordinated very carefully," says Lane.

Lubchenco, like Holdren, is a past president of the American Association for the Advancement of Science. A marine ecologist, she has spoken out against overfishing and done research in the hypoxic, or dead, zones that can be caused in some areas by fertilizer run-off. As head of NOAA she will have jurisdiction over a wide range of issues including the National Marine Fisheries Service and the National Weather Service.

Dealing with fisheries "will be one of her major challenges", says John Byrne, who headed NOAA during the administration of Ronald Reagan and is a former president of Oregon State University. Industry groups are wary of her pro-conservation stances, but Byrne thinks that Lubchenco is up to the challenge of running the agency. "It needs someone to respond to issues such as climate change, pressure on coastal zones, ocean pollution and over-fishing in a firm way. She will do that," he says.

Another appointment in Obama's environmental team is Ken Salazar, a Democratic senator from Colorado, to head the Department of the Interior. Salazar is known as a middle-of-theroader who has protested against Bush administration plans to expand oil-shale development in the American west, but who has also supported offshore drilling. The agency oversees the US Fish and Wildlife Service, which has been buffeted in recent years over its handling of species listings under the Endangered Species Act. Eric Hand and Alexandra Witze, with additional reporting by Ashley Yeager.

\title{
Universities struggle as value of endowments falls
}

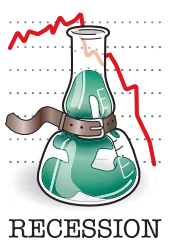

WATCH
Some large research universities have suffered double-digit declines in their multibillion-dollar endowments since the autumn credit crunch and stock market collapse. The endowments have also become increasingly cash-poor precisely when they might be expected to compensate for downward pressures on academic budgets. The declines are presenting universities with tough choices: fire sales of endowment assets, or budgetary trimming in the form of pay cuts, freezes on hiring and deferred construction projects.

"It's a very big problem," says John Walda, president of the National Association of College and University Business Officers (NACUBO) in Washington DC. "A good number [of endowments] are seeing about a $30 \%$ decline since last year."

Harvard University announced in December that its endowment, the world's largest and worth $\$ 36.9$ billion at mid-year, had dropped $22 \%$ from that amount by the end of November - with worse expected to come. As of mid-December, the world's second-largest endowment, that of Yale University, had fallen $25 \%$ since mid-year, when it stood at $\$ 22.9$ billion.
In some ways, the big universities have been a victim of their own success. As endowments experienced double-digit increases nearly every year through the 1990s and 2000s, universities have become ever more dependent on them in their overall budgets - even as endowment payouts remained roughly constant at around $5 \%$ per year. Ten years ago, Harvard's endowment paid for a third of the operating budget of the school of arts and sciences; now it covers more than half of the \$1.16-billion budget.

Endowments are suffering now partly because of the very investment methods they used to beat the broader markets year after year. Universities with endowments bigger than $\$ 1$ billion - there were 76 of them in the United States in 2007, according to NACUBO - kept much of their money in more volatile 'alternative' investments that are 'illiquid', or difficult to convert into cash quickly, such as hedge funds and venture capital. By comparison, institutions with endowments of less than \$25 million had a nearly opposite, more conservative approach, with much of their money being kept in cash and fixed-income assets (see chart).

John Nelson, an analyst with Moody's in New York, says the alternative-investment approach is smart: even in the bear market, when share prices are falling, the stock

\section{US UNIVERSITY ENDOWMENTS: A breakdown of asset classes}

Universities with investments

greater than $\$ 1$ billion

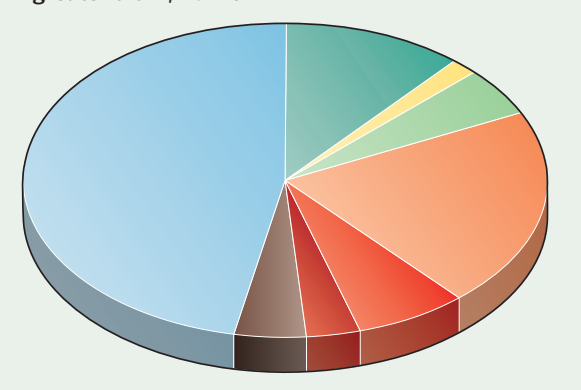

$\square$ Equity

Hedge funds $\square$ Fixed income

$\square$ Private equity
Universities with investments of $\$ 25$ million or less

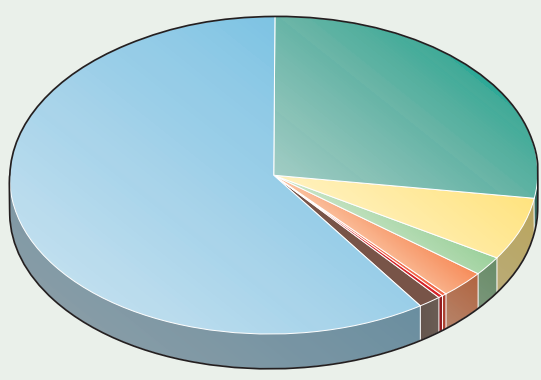




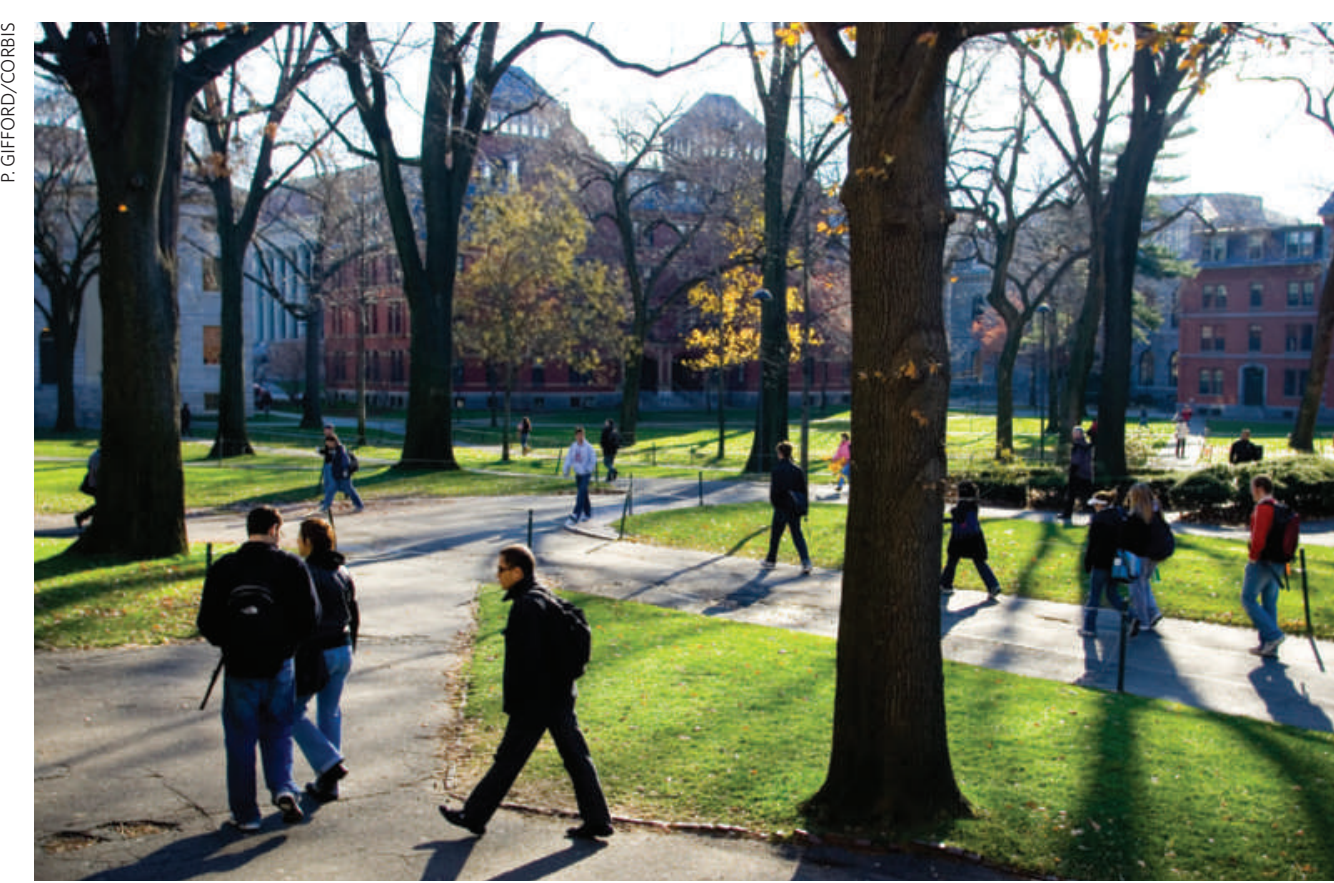

Walking into the unknown: Harvard University's endowment has lost $22 \%$ of its value since June, and may lose more.

18 December by the National Association of Independent Colleges and Universities, half of the 371 college and university presidents who responded reported freezing new hiring. In addition, $22 \%$ reported freezing salaries, and more than two-thirds were planning to raise tuition fees for the next academic year. Their manoeuvres stem partly from falling endowments, but also from concerns such as greater difficulty in raising funds and declining student enrolment numbers.

The endowment phenomenon is largely American, where there is a long tradition of private fund-raising in higher education. In Europe, the only two universities with multibillion-dollar endowments are Oxford and Cambridge in the United Kingdom. By and large, big research universities outside the United States are much more dependent on public funding,

$>$ portfolios of big universities have fared better than the Standard and Poor's 500 share index, which dropped $31 \%$ from 30 June to mid-December.

But alternative investments, in addition to being illiquid, can also suck up cash from elsewhere. Hedge-fund managers, for example, require periodic new investments known as 'cash calls'. These represent a problem at a time when universities need cash for salaries and construction projects and credit is hard to come by. "The tough choice that endowment managers face now is, 'when are we going to be forced to sell some of these assets in the down market?'” says Nelson. Some managers, such as those at Harvard, are already trying to sell assets off for far less than they had been worth, according to reports in The New York Times and The Wall Street Journal.

Even knowing what the alternative assets are worth is a challenge. Yeshiva University in New York City revealed that $\$ 110$ million in investments $-8 \%$ of the university's endowment - had evaporated in the investment scheme created by Bernard Madoff, who was arrested on 11 December and charged with fraud that may have cheated investors of $\$ 50$ billion (see 'Medical charity folds after investment losses', page 16). The current climate, says Walda, "will lead to more scrutiny of the underlying value of investments".

The effects on departmental hallways have been varied and will probably play out over several years, as most endowments base their payouts on a principal amount smoothed by a three-year rolling average. Harvard has put a partial hiring freeze in place. Stanford University in Palo Alto, California, will trim its budget next year by $5 \%$ by postponing new construction, controlling salaries and cutting some jobs. The chancellor of Washington University in St Louis, Missouri, has promised to take a symbolic pay cut of nearly $10 \%$ off his half-a-million-dollar salary. The Georgia Institute of Technology in Atlanta is trimming its landscaping budget; the University of Hawaii is turning off its weekend air-conditioning; and the Field Museum of Natural History in Chicago, Illinois, is cutting its budget by $15 \%$ after the value of the museum's endowment plunged by nearly US $\$ 100$ million (31\%) in the past six months (see Nature doi:10.1038/ news.2008.1333; 2008).

\section{Making do}

At the California Institute of Technology in Pasadena, endowment managers had started putting more money into cash and cash-equivalent assets in September, says spokesman Jon Weiner, and the university expects to weather the storm without a hiring freeze.

Few, however, are as optimistic about their prospects. In a survey released on says Thomas Estermann of the European University Association in Brussels. "Losing a higher percentage of public funding will be much worse for them," he says. That is also the case for small universities in the United States, which are worried about budget cuts at the state level because their endowments won't be bailing them out. The 1,600 private US institutions have a median endowment of only $\$ 16$ million, according to 2007 data from the US Department of Education. Most public universities have similarly small endowments, with the exception of a 